\title{
Bilateral Triad of Persistent Median Artery, a Bifid Median Nerve and High Origin of its Palmar Cutaneous Branch. A Case Report and Clinical Implications
}

\author{
Tríada Bilateral Correspondiente a Arteria Mediana Persistente, Nervio Mediano Bífido \\ y Origen Alto de la Rama Cutánea Palmar. Reporte de Caso e Implicancias Clínicas.
}

Olutayo Ariyo* \& John Shea*

ARIYO, O. \& SHEA, J. Bilateral triad of persistent median artery, a bifid median nerve and high origin of its palmar cutaneous branch. A case report and clinical implications. Int. J. Morphol., 34(3):997-1001, 2016.

SUMMARY: We report the association of a persistent median artery, a bifid median nerve with a rare very high origin palmar cutaneous branch, presenting bilaterally in the upper limb of a 75-year-old female cadaver. The persistent median nerve with a bifid median nerve has been reported in patients presenting with carpal tunnel syndrome. Reports of this neurovascular anomaly occurring in association with a high origin palmar cutaneous branch however, are few. This subset of patients is at risk of inadvertent nerve transection during forearm and wrist surgery. Pre-operative magnetic resonance imaging (MRI) and high resolution sonography (HRS) can be used to screen this triad. MRI can reveal if the patient's disability is associated with a persistent median nerve, a bifid median nerve. HRS can help identify a palmar cutaneous branch of the median nerve that arises in an unexpected high forearm location. Such knowledge will help surgeons in selecting the most appropriate surgical procedure, and help avoid inadvertent injury to cutaneous nerves arising in unexpected locations. In patients presenting with a bilateral carpal tunnel syndrome, hand surgeons should consider very high on the list of differential diagnosis a persistent median artery with a concomitant bifid median nerve, with a high suspicion of a possible bilateral occurrence of a bilaterally high arising palmar cutaneous branch of the median nerve.

KEY WORDS: Carpal tunnel syndrome; High arising palmar cutaneous branch; Inadvertent ligation; Persistent median nerve; Bifid median nerve.

\section{INTRODUCTION}

A bifid median nerve $(\mathrm{MN})$ and persistent median artery (PMA) are anatomic variations reported extensively in surgical literature, but with fewer reports of these variants accompanied by a high arising palmar cutaneous branch of the median nerve. The median artery is a transitory embryological structure that regresses normally in the second month of intrauterine life (DeVriese, 1902) but may persist in adult life in the palmar or antebrachial pattern depending on its vascular territory. Both median arteries we are reporting are large, long and they both reach the palm, representing the embryonic type reported by Salmon \& Dor (1933). Despite extensive reports of the concomitant occurrence of the bifid median artery and PMA, Lindley \& Kleinert (2003) found no direct correlation between them, but reported a case of the bifid median nerve with an accompanying accessory muscle belly of the long finger flexor superficialis. Rodríquez-Niedenführ et al. (1999) reported a $20 \%$ incidence of the palmar type of the PMA in the adult, being more frequent in females than in males [1.3 (ratio) 1], occurring unilaterally more than bilateral [5 (ratio) 1] and slightly more frequent on the right than on the left [1.1 (ratio)1] The palmar cutaneous branch of the median nerve (PCB) is purely sensory, customarily branches from the median nerve, and supplies sensory sensation to the palm and variable areas over the thenar and hypothenar eminences. Several variants of the PCB have been reported in literature including the coexistence of a high arising $\mathrm{PCB}$ with a PMA and bifid median nerve. Bezerra (1986) reported an average length of $5.24 \mathrm{~cm}$ for the PCB from its origin laterally from the median nerve to the distal palmar crease. The occurrence of the triad of a PMA, bifid MN as well as a high arising PCB existing not just unilaterally but bilaterally is very rare, and their clinical significances are discussed. 


\section{CASE REPORT}

During routine dissection by Arcadia Physician Assistant Students at the SKMC of Thomas Jefferson University, Philadelphia, we observed that each ulnar artery initially gave off an independent posterior interosseous artery, followed by a trifurcation yielding the anterior interosseous artery, the PMA and the continued ulnar artery (Fig. 1). Both PMA in the distal forearm were placed between 2 heads of their respective bifurcating median nerves (Figs. $2 \& 3$ ). We also observed a bilaterally slender and high - arising PCB of the $\mathrm{MN}$, as illustrated here in the right upper limb (Fig. $3)$. Photographs were taken with a Nikkon camera.

The median artery in both limbs were of the palmar variety, and about $5 \mathrm{~cm}$ from the distal palmar crease, we observed splitting of the MN bilaterally (Figs. 2 \& 3) Both radial / lateral heads of the bifid MN were bigger than that of their ulnar / medial counterparts (Figs. $2 \& 3$ ). Each PMA crossed over its respective radial head of the bifid $\mathrm{MN}$ and were placed centrally between the 2 heads of the bifid MN, a relationship maintained in coursing inferiorly in the forearm and in their passage through the carpal tunnel, posterior to the flexor retinaculum (Fig. $2 \& 3$ ).

Both PMA contributed to both the ulnar and radial arteries in the formation of the superficial palmar arch. Both PMA were carefully examined to exclude additional extra morphologies such as calcification, arterio-venous malformation, vessel aneurysms or any other abnormal nonvascular variants including any accessory muscle belly accompanying the MN in the tunnel. All these were found to be negative.

We also observed bilateral occurrence of an unusually high arising PCB of the median nerve, each arising proximally in the forearm and travelled along the radial side of the median nerve. The right $\mathrm{PCB}$ measured $18 \mathrm{~cm}$ in length from its origin to the distal palmar crease (Fig. 3) while the left was slightly shorter and measured about $15 \mathrm{~cm}$ (not shown). We did not observe any communication between the PMA and the ulnar artery in the forearm except in the formation of the radio-medio-ulnar variety of the superficial palmar arch in the hand.

\section{DISCUSSION}

Both MA encountered in our cadaver had failed to be transitory during embryonic development, but instead were primitive arterial patterns that had been selected to persist at birth. Lippert \& Pabst (1985) and O'Rahilly \& Müller (1992) are earlier workers with the sprouting theory on embryological development of the arteries of the upper limb which had been found obsolete. The current thinking is that of Rodríquez-Niedenführ et al. (2003) suggesting that these arterial patterns develop from an initial capillary plexus, by a proximal to distal differentiation, due to maintenance, enlargement and differentiation of certain capillaries and the regression of others. The bilateral MA of the palmar variety being reported represents the early embryonic pattern which instead of regressing had been maintained. Currently, there are no clarifications as what influences the determination of the selection of such or other primitive patterns that are seen at birth (RodríquezNiedenführ et al., 2003).

A bifid MN and PMA are anatomic variations reported extensively in the surgical, radiologic and cadaveric dissection studies. Lindley \& Kleinert reported a $3.4 \%$ incidence of high bifurcation of the $\mathrm{MN}$ associated with a PMA in the course of 526 elective carpal tunnel releases. Both PMA in our report originated from the trifurcation of the ulnar artery after the ulnar artery has given rise independently to the posterior interosseous artery. This is in contrast with the most common origin of the PMA, which usually originates between the caudal angle between common interosseous artery (Rodríquez-Niedenführ et al., 1999). Walker et al. (2013) reported a $3.7 \%$ incidence of the bifid nerve, $8 \%$ with a concomitant occurrence with a PMA. Other documented anomalies related to motor branch of the MN besides the bifid MN include ulnar and anterior take off of the motor branch, transligamentous and subligamentous course of the motor branch (Lindley \& Kleneirt).

Reported variants of the PCB of the median nerve are limited. Taleisnik et al. (1973) reported a transligamentous course piercing the transverse carpal ligament and a second variant in which the PCB courses ulnar to the median nerve and an unusually long length of the nerve. Mofikoya \& Ugburo (2012) reported a $4.5 \mathrm{~cm}$, plus or minus 2.1 SD for the PCB between its origin to the distal crease and found the terminal distal branching pattern of the nerve to be highly variable, while Bezerra et al. reported an average length of $5.24 \mathrm{~cm}$ for the PCB, with a range from $2.05 \mathrm{~cm}$ to $8.93 \mathrm{~cm}$. Both the left and right PCB (15 cm and $18 \mathrm{~cm}$ respectively) in our report were much longer than this average. Tsuruo et al. (2007) encountered PMA bilaterally in the forearms and hands in a 78 year old Japanese male cadaver, but there was no 


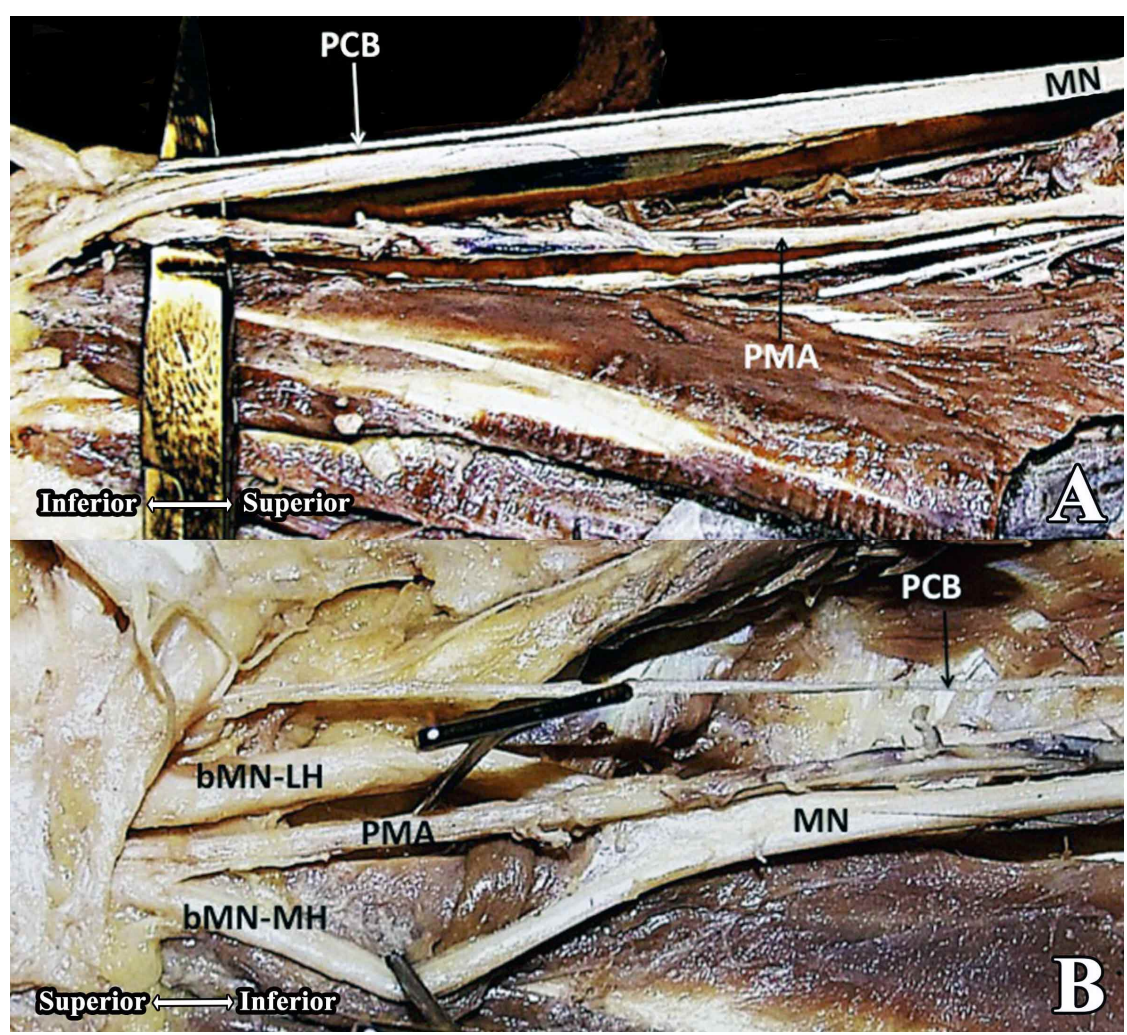

Fig. 1. A. This image shows a high arising palmar cutaneous branch of the median nerve originating very high in the forearm. MN; median nerve, PMA; persistent median artery. B. This image shows a centrally placed PMA between the 2 heads of the bifid median nerve in the right forearm. Note the bigger size of the lateral branch of the bifid median nerve. MN, median nerve; PMA; persistent median nerve, bMN - LH bifid median nervelateral head, bMN-MH, bifid median nerve -media 1 head.

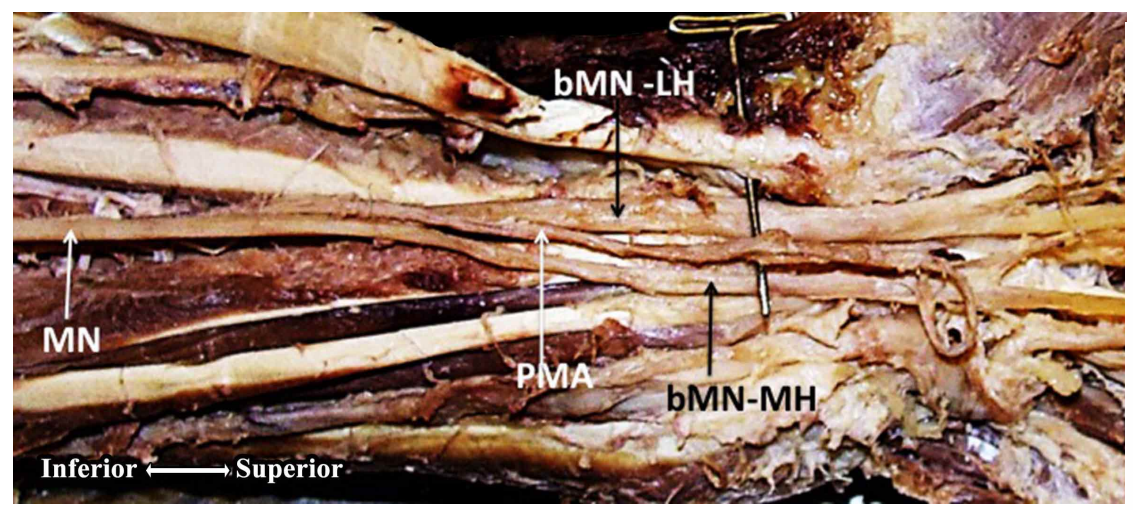

Fig. 2. This image shows a centrally placed PMA between the 2 heads of the bifid median nerve in the left forearm. MN, median nerve; PMA; persistent median nerve, bMN -LH bifid median nerve- lateral head, bMN-MH, bifid median nerve -medial head.

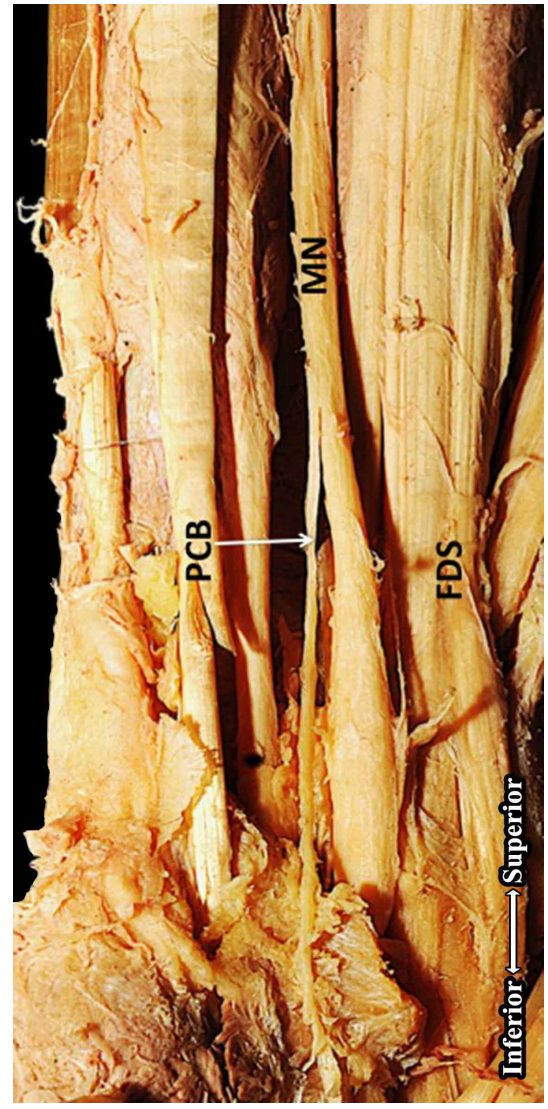

Fig. 3. This image shows the usual origin of the palmar cutaneous branch of the $\mathrm{MN}$ (approximately about $5 \mathrm{~cm}$ from the distal palmar crease). FDS- tendon of flexor digitorum superficialis.

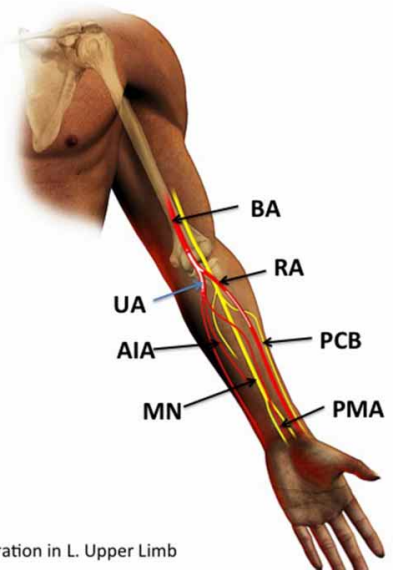

Fig. 4. Medical Image Illustration. This is an illustration of the PMA placed between the 2 heads of the MN distally. The PCB here is much higher arising when compared to its normal counterpart (Fig. 3). 
report of the presence of a high arising PCB, while Sañudo et al. (1994) reported a rare case of a right human forearm with a PMA in combination with a PCB of high origin, but they did not mention the length of this variant. Dysesthesiae of the of the palm and the skin of the base of the thumb were among the series of symptoms experienced by patients operated for CTS, reported as infrequent following carpal tunnel release surgeries.

Clinical implications of this triad include trauma to the PMA and the superficial placement of the PMA which makes the artery more prone to inadvertent ligation, with the possibility of extremity devascularisation, most especially with an absent radial or ulnar artery. Ultrasonography may help in the detection of atypical vascular structures within the carpal tunnel that may be of clinical importance before carpal tunnel release. Preoperative Doppler and ultrasonography may reveal the presence of a PMA and the existence of a variant PCB which would enhance better planning and reduction of iatrogenic complications, especially those involving surgical procedures high up in forearm. Several variant anatomic structures including extra muscle bellies, tendons coursing deep into the carpal canal as a tenth tendon as well as anomalies of the MN including the bifid $\mathrm{MN}$, with or without a concomitant PMA have been implicated in the causation of a CTS. With such a plethora of etiological factors, anticipating and understanding unexpected anatomic variants during CTS surgical procedures would enhance the surgeon's ability to perform a safer surgical intervention, helping in the reduction of inadvertent iatrogenic complications and improvements in patient's comfort and satisfaction. Lindley \& Kleinert reported a case of a patient with high bifurcation with a fullness noted in the forearm before surgery requiring proximal extensile exposure. A co-existence of an unsuspected high arising PCB in such a case can easily lead to inadvertent ligation to the nerve originating so high in the proximal forearm region.

In cases of a diagnosed bilateral CTS, concomitant occurrence of a bifid MN and PMA should be high on the list of differential diagnosis, while at the same time, with the possibility of a likely co-existing high arising PCB contemplated.

Sonography, may reveal the presence of a high origin variant of the PCB and a bifid $\mathrm{MN}$ in suspected case of CTS. This information is of value to the Hand surgeon committed to minimizing complications including inadvertent ligation of the PCB. The latter presents with local numbness, perceived immediately following surgery. Development of a neuroma later can be particularly distressing, prolonging disability time and severe impairment of hand function.

\section{ACKNOWLEDGEMENTS}

Many thanks the medical students who did initial dissection on this cadaver. Support and encouragement were received from Prof .Schmidt, the Divisional Head, and Prof. Stephen Peiper, the Chairman of the Department for encouraging scholarly activities. To our cadaver, immense thanks for contributing to knowledge, even after death.

ARIYO, O. \& SHEA, J. Tríada bilateral correspondiente a arteria mediana persistente, nervio mediano bífido y origen alto de la rama cutánea palmar. Reporte de caso e implicancias clínicas. Int. J. Morphol., 34(3):997-1001, 2016.

RESUMEN: En este estudio se presenta la disposición bilateral de una arteria mediana persistente, un nervio mediano bífido con ramo cutáneo palmar de origen alto, en los miembros superiores de un cadáver de sexo femenino de 75 años de edad. Clínicamente se asocia la presencia del nervio mediano bífido en pacientes con síndrome de túnel carpiano. Sin embargo, son escasos los informes de esta anomalía neurovascular en asociación con un ramo cutáneo palmar del nervio mediano de origen alto. Este subconjunto de pacientes podría sufrir de transección del nervio durante la cirugía de antebrazo y de la muñeca. Se recomienda utilizar la imagen preoperatoria de resonancia magnética (RM) y sonografía de alta resolución (SAR) para detectar esta tríada. La RM puede revelar si la discapacidad del paciente se asocia con un nervio mediano persistente, un nervio mediano bífido. SAR puede ayudar a identificar un ramo cutáneo palmar del nervio mediano que surge en una situación alta del antebrazo en forma inesperada. Tal conocimiento ayudará a los cirujanos en la selección del procedimiento quirúrgico más apropiado, y a evitar una lesión inadvertida de nervios cutáneos que surgen en lugares inesperados. En los pacientes que presentan un síndrome del túnel carpiano bilateral, los cirujanos de mano deben considerar como prioridad en la lista de diagnóstico diferencial una arteria mediana persistente con un nervio mediano bífido concomitante, con una alta sospecha de una posible aparición bilateral de un ramo cutáneo palmar bilateral alto que surja del nervio mediano.

PALABRAS CLAVE: Síndrome de túnel carpiano; Ramo cutáneo palmar bilateral alto; Ligadura inadvertida; Nervio mediano persistente; Nervio mediano bífido. 
ARIYO, O. \& SHEA, J. Bilateral triad of persistent median artery, a bifid median nerve and high origin of its palmar cutaneous branch. A case report and clinical implications. Int. J. Morphol., 34(3):997-1001, 2016.

\section{REFERENCES}

Bezzerra, A. J.; Carvalho, V. C. \& Nucci, A. An anatomical study of the palmar cutaneous branch of the median nerve. Surg. Radiol. Anat., 8(3):183-8, 1986.

De Vriese, B. Recherches sur l'évolution des vaisseaux sanguins des membres chez l'homme. Arch. Biol., 18:665-730, 1902.

Lindley, S. G. \& Kleinert, J. M. Prevalence of anatomic variations encountered in elective carpal tunnel release. J. Hand Surg. Am., 28(5):849-55, 2003.

Lippert, H. \& Pabst, R. Arterial Variations in Man. Munich, J. P. Bergmann-Verlag, 1985. pp.71-3.

Mofikoya, B. O. \& Ugburo, A. O. Anatomic variations in the palmar cutaneous branch of the median nerve among adults in Lagos, Nigeria. Niger. J. Surg., 18(2):85-7, 2012.

O’ Rahilly, R. \& Müller, F. Human Embryology \& Teratology. New York, Wiley-Liss, 1992. pp.245-9.

Rodríquez-Niedenführ, M.; Sañudo, J. R.; Vázquez, T.; Nearn, L.; Logan, B. \& Parkin, I. Median artery revisited. J. Anat., 195 (Pt. 1):57-63, 1999.

Rodríguez-Niedenführ, M.; Vazquez, T.; Parkin, I. G. \& Sañudo, J. R. Arterial patterns of the human upper limb: Update of anatomical variations and embryological development. Eur. J. Anat., 7 (Suppl. 1):21-8, 2003.

Salmon, M. \& Dor, J. Les Artères des Muscles des Membres et du Tronc. Paris, Masson, 1933. pp.53-5.

Sañudo, J. R.; Chikwe, J. \& Evan, S. E. Anomalous median nerve associated with persistent median artery. J. Anat., 185 (Pt. 2):447-51, 1994.

Taleisnik, J. The palmar cutaneous branch of the median nerve and the approach to the carpal tunnel. An anatomical study. J. Bone Joint Surg. Am., 55(6):1212-7, 1973.

Tsuruo, Y.; Ueyama, T.; Ito, T.; Nanjo, S.; Gyoubu, H.; Satoh, K.; Iida, Y. \& Nakai, S. Persistent median artery in the hand: a report with a brief review of the literature. Anat. Sci. Int., 81(4):242-52, 2007.

Walker, F. O.; Cartwright, M. S.; Blocker, J. N.; Arcury, T. A.; Suk, J. I.; Chen, H.; Schulz, M. R.; Grzywacz, J. G.; Mora, D. C. \& Quandt, S. A. Prevalence of bifid median nerves and persistent median arteries and their association with carpal tunnel syndrome in a sample of Latino poultry processors and other manual workers. Muscle Nerve, 48(4):539-44, 2013.

\author{
Corresponding Author: \\ Olutayo Ariyo MBBS, MBA. \\ Dept. of Pathology \\ Anatomy and Cell Biology \\ SKMC at Thomas Jefferson University \\ Philadelphia. PA 19050 \\ USA
}

Email: Olutayo.ariyo@jefferson.edu

Recibido :15-02-2016

Aceptado:04-07-2016 